\title{
APPLICATION EXAMPLES FOR THE DIFFERENT MEASUREMENT MODES OF ELECTRICAL PROPERTIES OF THE SOLAR CELLS
}

\section{PRZYKŁADY ZASTOSOWAŃ RÓŻNYCH TRYBÓW POMIARU WŁASNOŚCI ELEKTRYCZNYCH OGNIW SŁONECZNYCH}

The aim of the paper was to apply the newly developed instruments 'Corescan' and 'Sherescan' in order to measure the essential parameters of producing solar cells in comparison with the standard techniques. The standard technique named the Transmission Line Method (TLM) is one way to monitor contacting process to measure contact resistance locally between the substrate and metallization. Nowadays, contact resistance is measured over the whole photovoltaic cell using Corescanner instrument. The Sherescan device in comparison with standard devices gives a possibility to measure the sheet resistance of the emitter of silicon wafers and determine of both $\mathrm{P} / \mathrm{N}$ recognition and metal resistance. The Screen Printing (SP) method is the most widely used contact formation technique for commercial silicon solar cells. The contact resistance of manufactured front metallization depends of both the paste composition and co-firing conditions. Screen printed front side metallization and next to co-fired in the infrared conveyor furnace was carried out at various temperature from $770^{\circ} \mathrm{C}$ to $920^{\circ} \mathrm{C}$. The silver paste used in the present paper is commercial. The investigations were carried out on monocrystalline silicon wafers. The topography of co-fired in the infrared belt furnace front metallization was investigated using the atomic force microscope and scanning electron microscope (SEM). There were researched also cross sections of front contacts using SEM microscope. Front contacts of the solar cells were formed on non-textured silicon surface with coated antireflection layer. On one hand, based on electrical properties investigations using Sherescan instrument it was obtained the knowledge of the emitter sheet resistance across the surface of a wafer, what is essential in optimizing the emitter diffusion process. On the other hand, it was found using Corescan instrument that the higher temperature apparently results in a strongly decreased contact resistance.

Keywords: Electrical Properties, Solar cells, Screen printing, Contact resistance

Celem pracy było zastosowanie niedawno opracowanych urządzeń „Corescan” i „Sherescan” do zmierzenia zasadniczych parametrów wytwarzanych ogniw słonecznych w porównani z standardowymi technikami. Standardowa technika nazywana metodą linii transmisyjnych TLM (ang. Transmission Line Method) jest jednym ze sposobów monitorowania procesu pomiaru rezystancji strefy połączenia elektrody z podłożem. Obecnie, rezystancja kontaktu ogniwa słonecznego jest mierzona przy użyciu urządzenia Corescan. Urządzenie Sherescan w porównaniu ze standardowymi urządzeniami daje możliwość pomiaru rezystancji powierzchniowej warstwy dyfuzyjnej emitera płytek krzemowych i rozpoznania typu przewodności P/N i rezystancji kontaktu. Obecnie większość krzemowych ogniw fotowoltaicznych produkowanych na skalę przemysłową wytwarza się z zastosowaniem metody sitodruku do nanoszenia przedniej i tylnej metalizacji. Rezystancja kontaktu wytworzonej przedniej metalizacji zależy zarówno od składu pasty i warunków wypalania. Elektrodę przednią nadrukowano metodą sitodruku, a następnie wypalano w piecu taśmowym w zakresie temperatury od $770^{\circ} \mathrm{C}$ do $920^{\circ} \mathrm{C}$. W niniejszej pracy zastosowano komercyjną pastę srebrną. Badania wykonano na płytkach krzemowych monokrystalicznych. Topografię powierzchni wypalanej w piecu taśmowym przedniej elektrody wykonano stosując mikroskop sił atomowych i skaningowy mikroskop elektronowy. Zbadano również przekroje poprzeczne przednich elektrod stosując skaningowy mikroskop elektronowy. Elektrody przednie ogniw słonecznych wytworzono na powierzchni krzemowej nieteksturowanej z naniesioną warstwą antyrefleksyjną. Na podstawie uzyskanych badań własności elektrycznych za pomocą urządzenia Sherescan stwierdzono, że w zakresie temperatury od $770^{\circ} \mathrm{C}$ do $920^{\circ} \mathrm{C}$, rezystancja właściwa kontaktu mieści się w zakresie $0,43 \div 1,01 \mu \Omega / \square$ i rezystancja warstwowa kontaktu mieści się w zakresie $0,28 \div 0,67 \mathrm{~m} \Omega / \square$ krzemowego ogniwa fotowoltaicznego. W wyniku badań własności elektrycznych wykonanych z wykorzystaniem urządzenia Corescan uzyskano szczegółową mapę powierzchni oporu styku pomiędzy emiterem a warstwą metalizacji ogniw słonecznych.

DIVISION OF MATERIALS PROCESSING TECHNOLOGY, MANAGEMENT AND COMPUTER TECHNIQUES IN MATERIALS SCIENCE, INSTITUTE OF ENGINEERING MATERIALS AND BIOMATERIALS, SILESIAN UNIVERSITY OF TECHNOLOGY, 18A KONARSKIEGO STR., 44-100 GLIWICE, POLAND

** VŠB-TECHNICAL UNIVERSITY OF OSTRAVA, ST. 17.LISTOPADU 15, 70833 OSTRAVA, CZECH REPUBLIC 


\section{Introduction}

In the crystalline silicon solar cell technology one of the current trends is to reach highest efficiency on the wafers of minimized thickness. The thickness must meet the limit of approximately $200 \mu \mathrm{m}$ caused by the difference of thermal expansion coefficients of $\mathrm{Si}$ and $\mathrm{Al}$, which is used for a back contact. To reach optimum solar cell efficiencies, it is necessary also to reduce resistance losses to a minimum. The resistance loss, which is subdivided in series resistance and parallel resistance losses is one type of loss. It is very important to design properly both the size and shape of front electrode for the sake of mineralization of this loss. For approximately $90 \%$ of solar cells produced in industry, metallization is applied by screen printing of metal paste, followed by electrical and mechanical contact formation performed by co-firing in high temperature a belt furnace [8-15].

Important parameters determining the quality of the contact formation are e.g. paste composition or metal powder from which the paths are made, as well as manufacturing conditions. To reduce the contact resistance, it is important to be able to measure it. One way is to measure it using the Transmission Line Method (TLM), which nowadays it is generally known. TLM in comparison with the Corescan is slow and it is not able to give information as a function of position. To summarize, the Corescan does not have these limitations. Corescan makes possible to carry out the measuring onto the following ways [1-6]:

1. Corescan: Map contact resistance \& finger resistance and interruptions of front side metallization in order to optimize \& diagnose processes and/or pastes.

2. Shunt scan: Locate shunts on cells in order to find out about their nature.

3. Voc scan: Voc distribution in order to find locations of e.g. increased recombination (on cells without front side).

4. LBIC scan: Current distribution in order to locate regions with lower bulk lifetime, optimise gettering and hydrogen passivation.
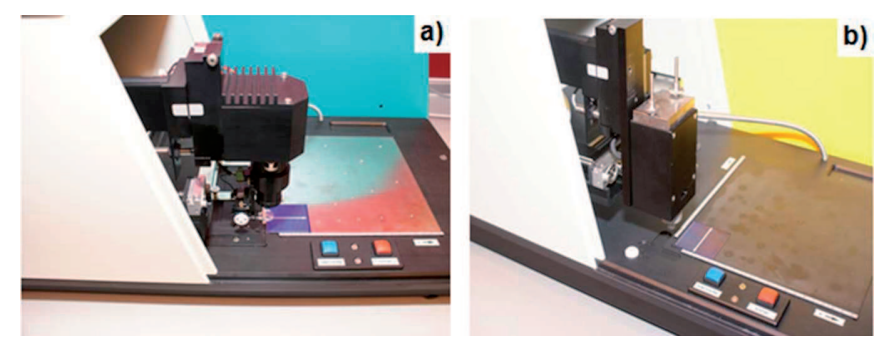

Fig. 1. Picture of instruments: a) Corescan, b) Sherescan

With the Corescan instrument (Fig. 1a), the contact resistance can be locally measured, and a complete scan for a 5 $\mathrm{cm} \times 5 \mathrm{~cm}$ solar cell depends on parameters (e.g. time) set up during a process.

The Sherescan instrument (Fig. 1b) uses a four probe measuring method. The measurements mode are the following [1]:

1. $\mathrm{P} / \mathrm{N}$ type recognition, it means a single point measurement in order to recognize $\mathrm{P}$ or $\mathrm{N}$ type of the semiconductor material;
2. Sheet resistance, it makes possible for detailed mapping and single measurement of sheet resistance of emitters;

3. Metal resistance, the determination of specific resistivity of metal metallization on a solar cell, e.g. the resistivity of the busbar.

\section{Experimental procedure}

The investigations were done on wafers (100) from monocrystalline silicon produced by Deutsche Solar (Germany) about the area of $25 \mathrm{~cm}^{2}$. Table 1 is presented the basic parameters of Si wafers. The wafers with thickness $\sim 230 \mu \mathrm{m}$ were applied in co-firing in the furnace.

TABLE 1

Testing material

\begin{tabular}{|c|c|}
\hline \hline \multicolumn{2}{|c|}{ The basic parameters of silicon } \\
\hline Type & $\mathrm{p}$ \\
\hline Doped & boron \\
\hline Thickness & $200 \pm 30 \mu \mathrm{m}$ \\
\hline Area & $5 \mathrm{~cm} \times 5 \mathrm{~cm}$ \\
\hline Resistivity & $1 \div 3 \Omega \cdot \mathrm{cm}$ \\
\hline
\end{tabular}

Front side metallization and connecting back contacts were printed using PV 145 and PV 124 paste produced by Du Pont company. Back side metallization was printed using CN53-101 Al conductor paste produced by Ferro company.

Technology of producing solar cells was performed in the Institute of Metallurgy and Materials Science in Krakow (Poland). The process steps for manufacturing solar cells included: chemical etching, $\mathrm{p}-\mathrm{n}$ junction formation, parasitic junction formation, surface passivation of solar cell $\left(\mathrm{SiO}_{2}\right)$, antireflection coating deposition $\left(\mathrm{TiO}_{x}\right)$, screen printing front and back contacts and next to co-firing them in the conveyor IR furnace.

These solar cell were manufactured to demonstrate usefulness of silver paste and to evaluate the contact resistance of the silver electrode-silicon junction. In order to obtain the smallest resistance value of the connection zone electrode with silicon substrate of solar cell and also uniform structure without pores, a series for solar cells were prepared by co-firing in the furnace (Tab. 2). The conveyor IR furnace was equipped with tungsten filament lamps, heating both the top and bottom of the conveyor. The following investigations were performed in this paper:

- The topography of both surface and cross section of front contacts using scanning electron microscope (SEM), confocal laser scanning microscope 5 (CLSM).

- Electrical properties of solar cells with front metallization made conventionally on computerized Solar - Lab positioning table, consisting in measurement of I-V curves of the photovoltaic solar cells.

- Electrical properties of solar cells, with front metallization made conventionally on Corescan and Sherescan instruments produced by SunLab BV a daughter company of ECN Solar Energy research Centre of the Netherlands. The Corescan instrument was apply to map the contact 
resistance of the front side metallization, locate shunts on solar cells and find out about their nature, find the locations of increased recombination (on research cells without front side metallization), find the regions on a solar cell with lower bulk lifetime. The Sherescan instrument was apply to recognize $\mathrm{P} / \mathrm{N}$ type of $\mathrm{Si}$ wafer and metal conductivity, as well sheet resistance of the Si wafer after diffusion process.

TABLE 2

Conditions of co-firing in the furnace silicon solar cells (the thickness of electrode: $15 \mu \mathrm{m}$ )

\begin{tabular}{|c|c|c|c|c|}
\hline \hline \multirow{2}{*}{ Series } & \multirow{2}{*}{ Paste symbol } & \multicolumn{3}{|c|}{ Temperature, ${ }^{\circ} \mathrm{C}$} \\
\cline { 3 - 5 } & & Zone I & Zone II & Zone III \\
\hline \multirow{2}{*}{1} & PV 145 & 530 & & 770 \\
\cline { 5 - 5 } & & & & 870 \\
\cline { 5 - 5 } & & & & 920 \\
\hline
\end{tabular}

\section{Results and discussion}

Based on metallographic observations in the scanning electron microscopy, it was found that front metallization obtained from silver PV 145 paste and co-fired in the furnace selective laser sintered show shows a porous structure (Fig. 2). Moreover, obtained electrodes demonstrate structure with different density grades depending on co-firing temperature. Front electrodes solar cells obtained at the lowest temperature of co-firing $\left(770^{\circ} \mathrm{C}\right)$ show a more porous structure rather than contacts sintered at the highest temperature $\left(920^{\circ} \mathrm{C}\right)$, which show very homogenous structure obtained in a consequence of contact pitting and their melting (Fig. 3).
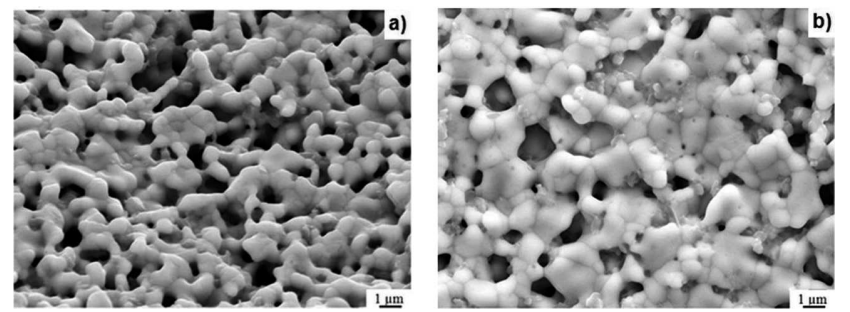

Fig. 2. SEM images of front contact layer co-fired in the furnace at the temperature: a) $770^{\circ} \mathrm{C}$, b) $920^{\circ} \mathrm{C}$ from $\mathrm{PV} 145$ paste on $\mathrm{Si}$ substrate without texture and with antireflection layer
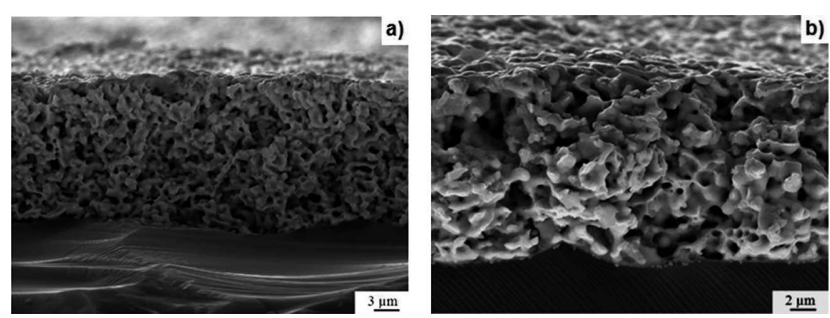

Fig. 3. SEM fracture images of front contact layer co-fired in the furnace at the temperature: a) $770^{\circ} \mathrm{C}$, b) $920^{\circ} \mathrm{C}$ from $\mathrm{PV} 145$ paste on $\mathrm{Si}$ substrate without texture and with antireflection layer
The thickness of test electrodes was determined based on the measurement of profile height three dimensional surface topography in the confocal scanning microscope (Fig. 4).

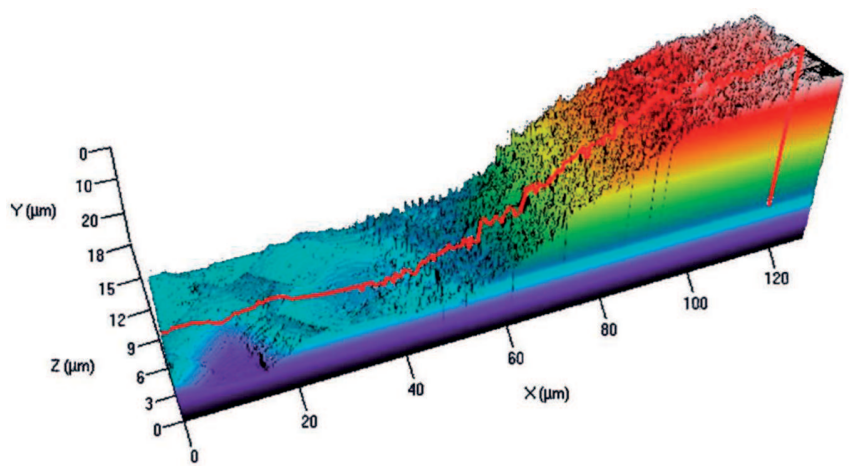

Fig. 4. Three-dimensional surface topography (CLSM) of the front electrode prepared from the PV 145 paste on a surface without texture and with antireflection layer co - fired in the furnace at $830^{\circ} \mathrm{C}$ temperature (example)

Based on both the metallographic and on the measurement of profile height three dimensional surface observations, it was found that the thickness testing front electrodes co-fired in the lowest temperature $770^{\circ} \mathrm{C}$ do not decrease or decreases the thickness is slight with relation to thickness of electrodes before their co-firing. As a result of investigations, the investigated testing front side contacts co-fired in the furnace show diverse thickness on cross-section in the range from 8 to 15 $\mu \mathrm{m}$.

Electrical properties of solar cells, with front side metallization obtained from PV 145 paste, co-fired in the furnace in the temperature range from 770 to $920^{\circ} \mathrm{C}$, determined from $\mathrm{I}-\mathrm{V}$ curves let confirmed that their efficiency is equal to $\mathrm{E}_{f f}=$ $0.10 \div 13.38 \%$ and fill factor is equal to $\mathrm{FF}=0.10 \div 0.65$ (Tab. $3)$. In solar cells with the smallest efficiency the following reduced short circuit current value was obtained $\left(\mathrm{I}_{s c}\right)$ of 67.69 $\mathrm{mA}$ and open-circuit voltage $\left(\mathrm{U}_{o c}\right)$ of $202.70 \mathrm{mV}$ (Tab. 4). It was found based on electrical properties that the surface morphology has a significant effect on value of conversion of the solar energy into electrical energy by solar cell.

Example scans on solar cells, in which front side metallization was screen printed and co-fired in the infrared at various temperature are given in this section in order to demonstrate the application of the Corescan for contact formation optimization. The temperature setting ranged from $\mathrm{T}+770^{\circ} \mathrm{C}$ to $\mathrm{T}+920^{\circ} \mathrm{C}$. The Corescan results are given in Fig. 5. In the Table 3, maximum FF is reached at $920^{\circ} \mathrm{C}$ temperature. The degradation in FF for the other temperature settings is caused by increased contact resistance losses. One of observations is that it is possible to deduce from the contact resistance distribution whether a cell is co-fired correctly or under-fired, because this gives possibility for an easy optimization of the temperature setting. The higher temperature apparently results in a strongly decreased contact resistance (Fig. 5). 
Electrical properties of silicon solar cells co-fired in furnace from PV 145 paste

\begin{tabular}{|c|c|c|c|c|c|c|c|c|c|}
\hline \hline \multirow{2}{*}{$\begin{array}{c}\text { Solar } \\
\text { cell } \\
\text { symbol }\end{array}$} & $\begin{array}{c}\text { Co-firing } \\
\text { temperature } \\
{\left[{ }^{\circ} \mathbf{C}\right]}\end{array}$ & \multicolumn{7}{|c|}{ Electrical parameters } \\
\cline { 5 - 9 } & $\mathbf{U}_{\mathbf{o c}}[\mathbf{m V}]$ & $\mathbf{I}_{\mathbf{s c}}[\mathbf{m A}]$ & $\mathbf{I}_{\mathbf{m}}[\mathbf{m A}]$ & $\mathbf{U}_{\mathbf{m}}[\mathbf{m V}]$ & $\mathbf{P}[\mathbf{m W}]$ & $\mathbf{F F}$ & $\mathbf{E}_{\mathbf{f f}}[\%]$ \\
\hline \multicolumn{7}{|c|}{ Photovoltaic solar cell without texture with coated antireflection layer } \\
\hline A & 770 & 202.70 & 67.69 & 6.41 & 208.20 & 1.34 & 0.101 & 0.10 \\
\hline B & 830 & 564.23 & 344.53 & 169.88 & 305.28 & 51.86 & 0.267 & 2.07 \\
\hline C & 920 & 590.93 & 866.76 & 740.32 & 451.76 & 334.45 & 0.653 & 13.38 \\
\hline
\end{tabular}

$\mathrm{I}_{s c}$ - short circuit current of solar cell, $\mathrm{I}_{m}$ - a current in maximum power point of solar cell, $\mathrm{U}_{m}$ - a voltage in maximum power point of solar cell, $\mathrm{U}_{o c}$ - open-circuit voltage of solar cell, $\mathrm{FF}$ - fill factor of solar cell, $\mathrm{P}$ - power of solar cell, $\mathrm{E}_{f f}$ - efficiency of solar cell

TABLE 4

Electrical parameters of photovoltaic solar cells co-fired in the furnace from PV 145 paste assigned based on fitting I-V curve of chosen solar cells to the theoretical two diode model

\begin{tabular}{|c|c|c|c|c|c|c|c|c|c|c|}
\hline \hline $\begin{array}{c}\text { Solar } \\
\text { cell } \\
\text { symbol }\end{array}$ & $\begin{array}{c}\text { Co-firing } \\
\text { temperature } \\
{\left[{ }^{\circ} \mathbf{C}\right]}\end{array}$ & \multicolumn{8}{c|}{ Electrical parameters } \\
\cline { 2 - 10 } & $\mathbf{I}_{\mathbf{p}}[\mathbf{m A}]$ & $\mathbf{R}_{\text {sh }}[\Omega]$ & $\mathbf{R}_{\mathbf{s}}[\Omega]$ & $\mathbf{I}_{\mathbf{s 1}}[\mathbf{A}]$ & $\mathbf{I}_{\mathbf{s} 2}[\mathbf{A}]$ & $\mathbf{A}_{\mathbf{1}}$ & $\mathbf{A}_{\mathbf{2}}$ & $\varepsilon[\%]$ \\
\hline \multicolumn{8}{|c|}{ Photovoltaic solar cell without texture with coated antireflection layer } \\
\hline $\mathrm{A}$ & 770 & 103.01 & 8.64 & 2.97 & $3.45 \mathrm{e}-7$ & $1.47 \mathrm{e}-4$ & 1 & 1.80 & 43.60 \\
\hline $\mathrm{B}$ & 830 & 721.45 & 1.29 & 0.29 & $4.88 \mathrm{e}-11$ & $4.60 \mathrm{e}-6$ & 1 & 2.03 & 3.79 \\
\hline $\mathrm{C}$ & 920 & 859.54 & 12.02 & 0.08 & $3.32 \mathrm{e}-11$ & $4.90 \mathrm{e}-5$ & 1 & 2.50 & 0.38 \\
\hline
\end{tabular}
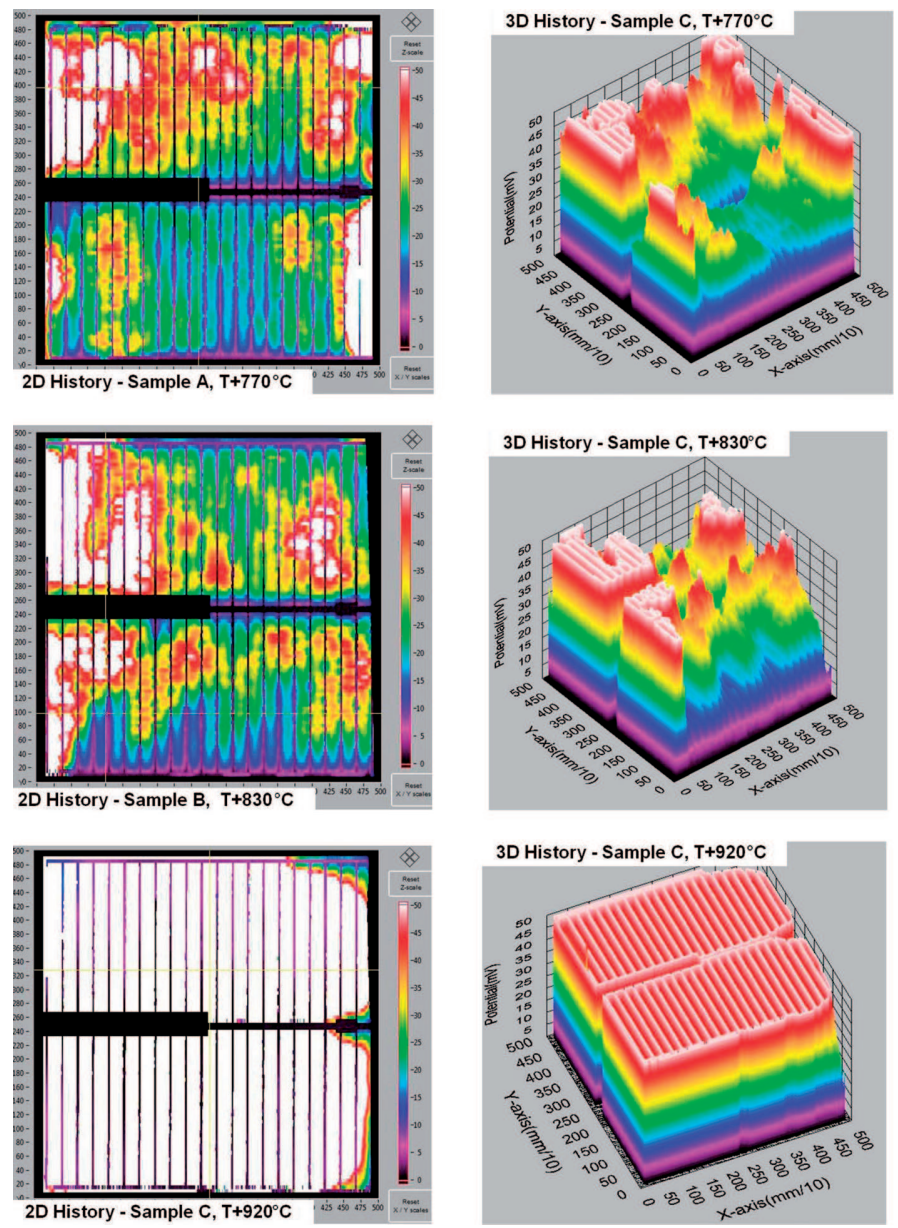

Fig. 5. Corescan potential mappings on cells co-fired at various temperature. Lighter areas have higher contact resistance
$\mathrm{P} / \mathrm{N}$ type of silicon wafers were recognized using Sherescan instrument equipped with mode of measurement: $\mathrm{P} / \mathrm{N}$ recognition (Fig. 6). As result of measurement was obtained $\mathrm{p}$ - type of silicon wafer (Fig. 6b). Figure 7 presents a typical cross mapping, which shows the sheet resistance values, with a high resistance area in the whole part. This way of mapping and representation, as used for semi-conductor applications, does enough for solar cell applications. As a result of measurement were obtained the following results: average: 47.6 $\Omega / \square$, standard deviation $1.1 \Omega / \square$, median $47.5 \Omega / \square$, max.49.0 $\Omega / \square$, min. $46.3 \Omega / \square$.
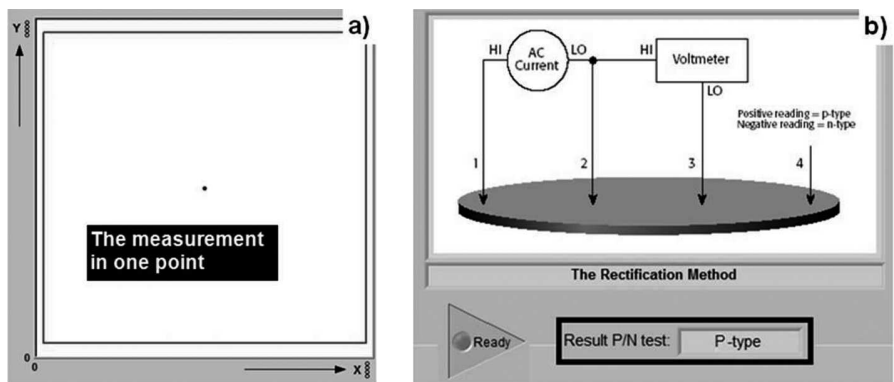

Fig. 6. Measurement of P/N determination on Si wafer (an example): a) a view of scan settings, b) a view of measurement result

Figure 8 presents the panel of the result of the metal resistance measurement. The data in the plot show the resistance across a silver busbar. From these data the sheet resistance, and also the specific resistivity of the metal were calculated (Tab. 5). The smallest metal resistance measurements were obtained for a $\mathrm{C}$ sample co-fired in the furnace in $920^{\circ} \mathrm{C}$ temperature. 

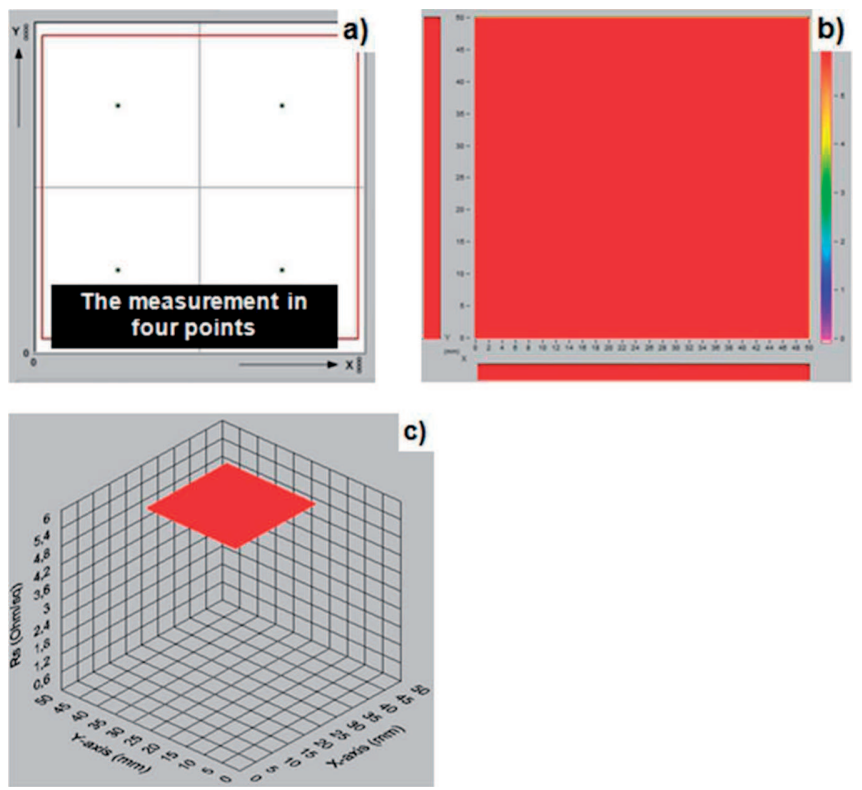

c)

Fig. 7. Procedure measurement of the emitter sheet resistance across the surface of a single wafer (an example): a) a view of scan settings, b) a view of measurement result, c) a view of three-dimensional measurement
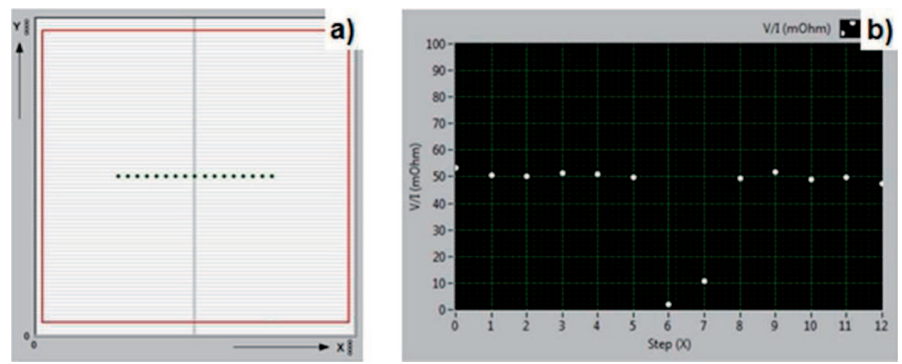

Fig. 8. Procedure measurement of specific resistivity of metal: a) a view of scan settings, b) a view of measurement results (example)

TABLE 5

The metal resistance measurements

\begin{tabular}{|c|c|c|c|}
\hline \hline \multirow{2}{*}{$\begin{array}{c}\text { Solar } \\
\text { cell } \\
\text { symbol }\end{array}$} & $\begin{array}{c}\text { Co-firing } \\
\text { temperature } \\
{\left[{ }^{\circ} \mathbf{C}\right]}\end{array}$ & \multicolumn{2}{|c|}{$\begin{array}{c}\text { Specific resistivity } \\
\text { of metal }\end{array}$} \\
\cline { 3 - 4 } & & $\begin{array}{c}\text { Sheet resistance } \\
\text { of metal } \\
{[\mathbf{m} \Omega / \square]}\end{array}$ & $\begin{array}{c}\text { Specific resistivity } \\
\text { of metal } \\
{[\mu \Omega \mathrm{cm}]}\end{array}$ \\
\hline $\mathrm{A}$ & 770 & 0.674 & 1.011 \\
\hline $\mathrm{B}$ & 830 & 0.390 & 0.586 \\
\hline $\mathrm{C}$ & 920 & 0.280 & 0.430 \\
\hline
\end{tabular}

\section{Summary}

On the basis of metallographic observation, it was found that the morphology a test electrode system deposited from paste PV 145 and co-fired in the furnace shows a porous structure, porosity grade depended on co-firing temperature. On the basis of electrical properties investigations using Sherescan instrument it was found that in the temperature range from $770^{\circ} \mathrm{C}$ to $920^{\circ} \mathrm{C}$ the specific resistivity of contact is equal
$0.43 \div 1.01 \mu \Omega / \square$ and the sheet resistance of metal contact is equal $0.28 \div 0.67 \mathrm{~m} \Omega / \square$ onto non-textured substrate having coated antireflection layer of silicon solar cells. On the basis of electrical properties investigations using Corescan instrument it was found that the higher temperature apparently results in a strongly decreased contact resistance.

\section{Acknowledgements}

Research was financed partially within the framework of the Scholarship No 51200863 of the International Visegrad Fund realized by Dr Małgorzata Musztyfaga.

The authors thank the staff of the Laboratory Photovoltaic, Institute of Metallurgy and Materials Science Polish Academy of Sciences for assist in the preparation of materials for testing.

\section{REFERENCES}

[1] http://www.sunlab.nl 03.09.2012.

[2] A.S.H. Van der Heide, J.H. B u l t man, J. Hoor ns t r a, A. S c hö n e cke r, G.P. W y e r s, W.C. S i n ke, Optimizing the front side metallization process using the Corescan - Proceedings 29th IEEE Photovoltaic Specialists Conference, New Orleans (Louisiana, USA), p. 340 (2002).

[3] A.S.H. Van der Heide, A. S chönecker, G.P. W y e rs, W.C. S in ke, Mapping of contact resistance and locating shunts on solar cells using Resistance Analysis by Mapping of Potential (RAMP) techniques - Proceedings 16th European Photovoltaic Solar Energy Conference, Glasgow (United Kingdom), p. 1438 (2000).

[4] A.S.H. Van d e r He i d e, M.J.A.A. G o r i s, Contact optimisation on lowly doped emitters using the corescan on non-uniform emitter cells, Proceedings $19^{\text {th }}$ European Photovoltaic Solar Energy Conference, Paris (France), 701 (2004).

[5] J. Hoornstra, A. Van der Heide, J. Bultman, A. W e b e r, Simple, detailed \& fast firing furnace temperature profiling for improved efficiency - Proceedings of the conference PV in Europe - From PV technology to energy solutions, Rome (Italy), 276 (2002).

[6] J. Hoornstra, A. Van der Heide, A. We eber, F. $\mathrm{Gr}$ a n e k, New approach for firing optimisation in crystalline silicon cell technology - Proceedings $19^{\text {th }}$ European Photovoltaic Solar Energy Conference, Paris (France), 1044 (2004).

[7] D.W. H a m e r, J.V. B i g g e r s, Technology of self-contained system, WNT, Warsaw, 1976 (in Polish).

[8] W. J un g, T. P i ot row s ki, S. S i korski, M. Li piń sk i, P. P a n e k, P. Z i ę b a, Study of Bulk Photovoltaic Effect and Photovoltaic Barrier Efect Distributions in Multicrystalline Silicon, Phys. Stat. Sol. (c) 4, 8, 2918-2922 (2007).

[9] L.A. D o b r z a ń s k i, Engineering Materials and material design: the basis learning about materials and metal science, Scientific and Technical Publishing House, Warsaw, 2006.

[10] L.A. D o b r z a ń s k i, M. M u s z t y f a g a, Effect of the front electrode metallization process on electrical parameters of a silicon solar cell, Journal of Achievements in Materials and Manufacturing Engineering 48, 2, 2, 115-144 (2011).

[11] L.A. Dobrzański, M. Muszty faga, A. D ryga ła, P. P a n e k, Investigation of the screen printed contacts of silicon solar cells from Transmissions Line Model, Journal of Achievements in Materials and Manufacturing Engineering, JAMME 41 1-2, 57-65 (2010).

[12] L.A. Do brzańs ki, M. Muszty f g a, A. D r ygała, Comparison of conventional and unconventional methods for 
the front side metallization of silicon solar cells, $14^{\text {th }}$ International Conference on Advances in materials and processing technologies. AMPT 2011, 284.

[13] P. Panek, K. Drabczyk, A. Focs a, A. S l a ou i, A comparative study of $\mathrm{SiO} 2$ deposited by PECVD and thermal method as passivation for multicrystalline silicon solar cells, Materials Science and Engineering B 165, 64-66 (2009).

[14] P. Panek, K. D rabczyk, H. C zternastek, E. Kusi or, P. Zięba, E. B ełtowska-Lehman, The In- fluence of surface texture and temperature deposition of $\mathrm{TiO}_{2}$ layer on crystalline silicon solar cells parameters, Archives of Metallurgy and Materials 53, 1, 103-106 (2008).

[15] P. Panek, K. Drabczyk, A. Foc s a, A. S l a ou i, A comparative study of $\mathrm{SiO}_{2}$ deposited by PECVD and thermal method as passivation for multicrystalline silicon solar cells, Materials Science and Engineering B 165, 64-66 (2009). 